\title{
INFERENSI DALAM WACANA TEBAK KATA DI ACARA WAKTU INDONESIA BERCANDA
}

\author{
Yusep Ahmadi F*, Diena San Fauziya \\ Pendidikan Bahasa Indonesia, IKIP Siliwangi, Indonesia \\ * Corresponding author: yusep-ahmadi-f@ikipsiliwangi.ac.id
}

\begin{tabular}{ll}
\hline \hline INFORMASI ARTIKEL & \multicolumn{1}{c}{ ABSTRAK } \\
\hline Sejarah Artikel & Penelitian ini merupakan penelitian wacana yang memfokuskan \\
Diterima: $2 / 10 / 2018$ & pada telaah inferensi. Penelitian ini dilatarbelakangi oleh \\
Direvisi: $31 / 5 / 2019$ & kebingungan atau kesalahpahaman yang dialami penyimak kuis \\
Disetujui: $2 / 6 / 2019$ & tebak kata acara Waktu Indonesia Bercanda (WIB) yang disiarkan \\
Tersedia Daring: $11 / 6 / 2019$ & di NET TV. Tujuan penelitian ini adalah untuk mengetahui dan \\
& mendeskripsikan pola inferensi pada wacana tersebut. Penelitian \\
Kata Kunci: & semacam ini belum banyak dilakukan terlebih dengan mengambil \\
Inferensi & wacana yang sedang hangat di masyarakat, yakni acara tebak kata \\
Analisis Wacana & Waktu Indonesia Bercanda'. Metode dalam penelitian ini adalah \\
Wacana Tebak Kata & kualitatif-deskriptif. Sumber data berasal dari website channel WIB \\
& di website youtube.com yang berupa tuturan-tuturan teka teki yang \\
& ada di acara Waktu Indonesia Bercanda (WIB) dan akun instagram \\
& WIB_Net www.instagram.com/wib_net/. Data dianalisis secara \\
& interpretatif melalui teori inferensi prinsip penafsiran lokal dan \\
& analogi. Hasil temuan menunjukkan bahwa pola inferensi dalam \\
& wacana tebak kata acara WIB memilki ketidakajegan. Sebagaian \\
& wacana berpola penafsiran lokal, berpola analogi sebagaian dari \\
& kata dalam teks. Selain itu, prinsip penafsiran lokal pun tidak \\
& sejalan dengan struktur teks, yakni terdapat pelanggaran terhadap \\
ejaan dan koherensi koteks. Hal ini munjukkan terdapatnya \\
pelanggaran-pelanggaran prinsip penafsiran lokal dan prinsip \\
analogi. Hal itu menimbulkan kegagalan pragmatik bagi para \\
penyimak wacana tersebut. Ketidakajegan inferensi dan \\
pelanggaran prinsip-prinsip inferensi inilah yang dimanfaatkan \\
acara tebak kata Waktu Indonesi Bercanda (WIB) dalam menarik \\
penyimak atau penonton agar merasakan penasaran dan lucu dari \\
acara tersebut.
\end{tabular}

Keywords:

Inference

Discourse Analysis

Discourse Guessing Words
This study belongs to discourse research that focuses on inference studies. This research is motivated by the confusion or misunderstanding experienced by the quiz participants when guessing the word riddles at Waktu Indonesia Bercanda (WIB), a quiz program which is broadcast on Net TV. The Purpose of this study is to find out and describe the inference patterns of the discourse. This kind of research has not been done much. The method used in this study is qualitative-descriptive. The data are analyzed interpretatively through the inference theory of local interpretation principles and analogy. The findings show that the inference patterns in the discourse of Waktu Indonesia Bercanda event has a discrepancy. Some discourse patterns show that local interpretations are analogous to that of the words in the text. In addition, the principle of local interpretation is not in line with the structure of the text as there is a violation of spelling and 
coexistence. This shows the existence of violations of the principle of local interpretation and the principle of analogy. It then leads to a pragmatic failure for the viewers. This lack of inference and violation of the principles of inference is used by the host of the quiz program to attract the viewers as they may feel attracted watching the program and find the discourse hilarious.

Copyright@2019, Yusep Ahmadi F, Diena San Fauziya This is an open access article under the CC-BY-3.0 license
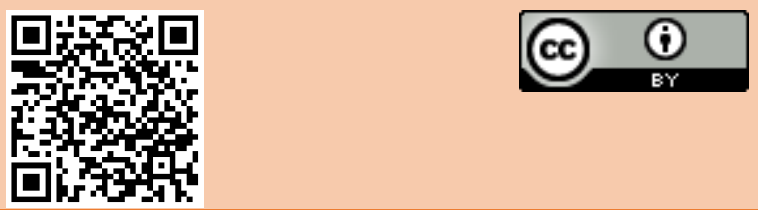

\section{PENDAHULUAN}

Kegiatan berbahasa merupakan kegiatan manusia yang pada dasarnya tidak bisa dilepaskan dari logika. Bahkan ada ungkapan bahasa adalah sarana berpikir 'vehicle of reason'. Setangkup dengan itu, berbahasa yang utuh sejatinya adalah ketika seseorang berwacana. Wacanalah yang biasa kita gunakan dalam komunikasi karena bentuk bahasa terebut merupakan yang terlengkap dan memiliki unsur-unsur pendukung makna (Wiyanti, 2016).

Waktu Indonesia Bercanda (WIB) merupakan salah satu acara di stasiun televisi yang hadir di hari Senin-Kamis pukul 18.00 WIB (WIB Terbaru) dan Jumat pukul 18.00 WIB (WIB Pilihan). Waktu Indonesia Bercanda (WIB) adalah salah satu program komedi yang menjelaskan sebuah topik yang berkaitan dengan kehidupan manusia, yang membedakan acara ini adalah penyampaian yang dibawakan dan dikemas dengan lucu dan tidak biasa. Kemasan acara yang mebuatnya berbeda dengan acara komedi yang lainnya adalah segmen permainan yang diawali dengan TTS (Teka-Teki Sulit) dan pilihan dari beberapa permainan seperti Kuis Sensus, Berpacu dalam Emosi, Kata Misteri. Hal inilah yang menjadikan setiap tuturan yang diucapkan mengandung banyak wacana yang sangat kompleks. Berdasarkan pengamatan terhadap fenomena tersebut banyak sekali permasalahan inferensi yang timbul antara pertanyaan dengan jawabannya.

Istilah wacana berasal dari bahasa Sansakerta wac/wak/vak, artinya berkata', berucap' (Mulyana, 2005). Kemudian Mulyana menyimpulkan bahwa wacana merupakan; perkataan' atau tuturan'. Secara linguistik wacana merupakan satuan bahasa terbesar dan terlengkap yang memiliki makna utuh. Wacana dibangun berdasarkan elemen-elemen kecil yang selalu digunakan dalam kehidupan manusia, mulai dari tuturan hingga konteks yang memberikan makna terhadap tuturan tersebut (Numertayasa \& Sutama, 2013). Melalui pemaknaan berdasarkan konteks, maka tuturan yan diucapkan akan memliki makna yang bersifat mengikat atau bebas (Ghufron, 2012).

Tindak tutur merupakan tindakan-tindakan yang ditampilkan melalui sebuah tuturan (Ghufron, 2012). Dapat disimpulkan wacana merupakan tuturan yang hadir dalam konteks tertentu yang melibatkan penutur dan lawan tutur. Di samping itu, wacana juga selalu hadir dalam tindak atau peristiwa komunikasi yang selalu mensyaratkan komunikator, pesan, dan komunikan. Hal itu sejalan dengan pendapat Musaffak (2015) bahwa wacana adalah segala bentuk komunikasi yang realisasinya bergantung pada konteks sosial yang melingkupi konteks komunikasi tersebut. Dalam kaitannya dengan komprehensi dan interpretasi terhadap wacana, seorang komunikan memiliki banyak alat untuk memahami wacana dengan memanfaatkan unsur-unsur ekternal wacana seperti, presuposisi, implikatur, referensi, konteks wacana, dan inferensi (Lestari, Artika, \& Indriani, 2016). 
Inferensi adalah bagian penting dalam unsur eksternal wacana yang dapat dimanfaatkan seorang komunikan atau lawan tutur ketika hendak memahami wacana. Inferensi atau inference secara leksikal artinya adalah kesimpulan. Berkait dengan itu, Mulyana (2005) mengartikan inferensi sebagai proses yang harus dilakukan peembaca yang secara harfiah tidak diungkapkan dalam wacana secara eksplisit. Inferensi (wacana) percakapan adalah proses interpretasi yang ditentukan oleh situasi dan konteks (Numertayasa \& Sutama, 2013). Mulyana (2005) pun sepaham dengan yang dikatakan Nurmatayasa dan Sutama yang menambahkan bahwa pengetahuan konteks sosiokultural menjadi aspek penting dalam memahami inferensi wacana.

Sementara itu, dalam pandangan Djajasudarma (2012) "interferensi terjadi bila proses yang harus dilakukan oleh pendengar atau pembaca untuk memahami makna secara harafiah tidak terdapat pada wacana yang diungkapkan oleh pembicara atau penulis. Penafsiran makna dapat pula ditopang oleh tuturan yang berurutan atau berkaitan dengan linearitas bahasa (Marwan, 2013). Penafsiran dengan memerhatikan ko-teks (unsur teks yang menopang), penafsiran lokal (konteks ruang dan waktu), dan prinsip analogi (Hanafiah, 2015).

Sementara itu, inferensi adalah tindakan akal budi berupa tindakan memunculkan sebuah proposisi yang dinamakan kesimpulan dari atau berdasarkan proposisi (proposisi-proposisi) anteseden (premis atau premis-premis) (Sidharta \& Gunarsa, 2016). Inferensi dapat dibedakan menjadi 2 jenis, yakni inferensi langsung (konversi dan obversi) dan tidak langsung (silogisme). Dapat disimpulkan bahwa inferensi merupakan mekanisme logika dalam menyimpulkan sebuah wacana (Anjani, 2013).

Penelitian-penelitian wacana yang pernah dilakukan di antaranya seperti yang dilakukan oleh Mujianto (2018a) dan Ahmadi, Darmayanti, Wahya (2017). Kedua penelitian tersebut memfokuskan pada wacana kritis yang tidak secara eksplisit menguraikan inferensi wacana. Sementara itu, penelitian yang dilakukan oleh Ahmadi (2016) yang berjudul "Analisis Modalitas Tuturan Ahok (Basuki Cahaya Purnama) lebih menekankan analisis terhadap modalitas tuturan. Adapun penelitian wacana yang berkaitan dengan inferensi masih sangat terbatas. Kebanyakan analisis wacana sepengamatan penulis banyak berfokus pada analisis wacana kohesi dan koherensi seperti penelitian Ahmadi dan Mahardika (2016), (Eriyanti, 2017), dan Mujianto (2018b) lebih menekanka pada analisis wacana secara kritis.

Sementara itu, sepengetahuan penulis analisis wacana berkait inferensi pernah dilakukan oleh (Nurshoimah \& Prabowo, 2016). Selanjutnya ada kajian inferensi yang dilakukan oleh (Surana, 2017), kajiannya menyoal inferensi dan problematika dalam pembelajaran analisis wacana. Penelitian tersebut mendeskripsikan berbagai masalah yang dihadapi siswa dalam mempelajari wacana. Penelitian Surana tidak membahas masalah inferensi yang berhubungan dengan wacana yang bersifat tebak-tebakan atau humor. Selian itu, ada penelitian yang dilakukan Wijoyanto (2018) judul "Hubungan Referensi-Inferensi dalam Wangsalan Sindhenan". Salah satu tujuan penelitiannya adalah mendeskripsikan hubungan referensi-inferensi dalam wangsalan sindhenan dan fungsi pragmastilistikanya. Dilanjutkan lagi dengan penelitian dengan fokus inferensi terhadap wacana drama berjudul Nihonjin No Shiranai Nihongo (Amin, 2018).

Beberapa penelitian tersebut menunjukkan belum ada penelitian inferensi wacana yang menyentuh dan menyoal inferensi yang terdapat dalam wacana tebak-tebakan atau tebak kata yang bersifat humor. Penelitian ini bertujuan untuk mengetahui inferensi dalam wacana tebak kata di acara waktu Indonesia bercanda. menarik dan penting untuk dilakukan. Oleh karena itu, penelitian ini setidaknya bermanfaat dan memberi informasi kepada para guru dan peneliti wacana dan untuk pengembangan kajian analisis wacana yang kian hari kian luas bidang kajiannya. Kondisi tersebut diakibatkan oleh fenomena bahasa yang saat ini terjadi di masyarakat tidak lagi berpola linear atau ajeg. 


\section{METODE}

Metode penelitian ini adalah metode kualitatif. Metode kualitatif merupakan prosedur yang menghasilkan data deskriptif berupa data tertulis atau lisan di masyarakat bahasa (Djajasudarma, 2012). Data dianalisis secara deskriptif dan peneliti sebagai instrumen penelitiannya. Sumber data diambil dari video youtube yang berisi rekaman tayangan acara Waktu Indonesia Bercanda (WIB) yang di dalamnya terdapat berbagai data pertanyaanpertayaan dalam teka-teki sulit acara tersebut. Sampel diambil dengan teknik purposif sampling. Diambil 3 episode tayangan yang berisisi 25 tuturan yang secara intonasi menandakan pertanyaan teka teki.

Sumber data berasal dari website channel WIB di website youtube.com yang berupa tuturan-tuturan teka teki yang ada di acara Waktu Indonesia Bercanda (WIB) dan akun instagram WIB_Net www.instagram.com/wib_net/ Yaitu akun instagaram resmi acara Waktu Indonesia Bercanda di Net TV yang di dalamnya memuat berbagai teka-teki/ tebak kata.

Teknik keabsahan data dengan cara trianggulasi, yakni data dibandingkan dari beberapa sumber untuk menemukan kesesuaian. Selain itu, data dinilai oleh beberapa ahli untuk menilai kerelevanan dan kredibilitas data hingga data dapat dikatakan valid.

\section{HASIL DAN PEMBAHASAN}

Data yang disajikan dalam pembahasan ini kalimat-kalimat tebak kata yang diambil dari website channel WIB di website youtube.com Waktu Indonesia Bercanda (WIB) dan akun instagram WIB_Net www.instagram.com/wib_net/ seperti pada Tabel 1.

Tabel 1

Uraian Data Inferensi dalam Acara WIB

\begin{tabular}{cl}
\hline No & \multicolumn{1}{c}{ Data } \\
\hline 1 & Orang yang pergi menjelajahi ke luar angkasa pasti... \\
\hline 2 & Hewan buas yang mencari ikan salmon di sungai biasanya... \\
\hline 3 & Alat musik yang dipukul... \\
\hline 4 & Hewan yang dipelihara di akurium... \\
\hline 5 & Kampung Rambutan, cililitan, lebak bulus adalah nama... \\
\hline 6 & Makanan khas jakarta yang terbuat dari telor dan laris manis... \\
\hline 8 & Si dul adalah anak... \\
\hline 9 & Monumen yang ada di Jakarta... \\
\hline 10 & Tokoh berkostum kelelawar yg melindungi gotham city... \\
\hline 11 & Saat memotret model. Kita biasanya pakai... \\
\hline 12 & Mang bawa gitar dan mencari nafkah di atas bis. Biasanya ... \\
\hline
\end{tabular}

Uraian data pada Tabel 1 merupakan temuan inferensi yang terdapat dalam acara Waktu Indonesia Bercanda (WIB). Dalam 3 episode yang digunakan sebagai sumber data, didapatkan sebanyak 25 tuturan yang mengandung inferesi. Dari 25 data tersebut, ditarik pemaparan dan pembahasan secara detail dalam uraian berikut.

\section{PEMBAHASAN}

Inferensi dapat dilakukan dengan dua cara yakni dengan prinsip analogi dan prinsip penafsiran lokal. 
Data 1: Orang yang pergi menjelajahi ke luar angkasa pasti...

Tersedia 8 kotak huruf, kotak huruf ke-8 T. Jawaban PAKENIAT

Dalam kuis ini, pengambilan inferensi terkadang dijebak terlebih dahulu oleh huruf-huruf yang tersedia. Pada data di Tabel 1 secara analogi atau pengetahuan umum/lazim orang yang menjelajahi ke luar angkasa disebut astronot. Akan tetapi, prinsip analogi ini dilanggar oleh data teks tersebut. Jawaban pakeniat selain melanggar prinsip analogi atau pengetahuan sosiokultural juga melanggar asas ejaan seharusnya jawaban pakeniat tidak ditulis serangkai tanpa spasi. Perlu inferensi lain untuk dapat masuk dalam maksud teks tersebut yakni dengan analogi yang keluar dari batas umum. Di sini terdapat permasalahan mekanisme inferensi dalam data tersebut. Secara penafsiran lokal pun jawaban pakeniat tidak memiliki hubungan terutama dengan koteks kata pasti. Logika kalimat ini jika menggunakan analogi yang jauh atau dalam penelitian ini dinamakan analogi lapis kedua, yakni kegiatan menyimpulkan suatu tuturan secara intutif yang tidak secara langsung beranalogi namun dengan menjelajahi berbagai kemungkinan informasi sosiokultural yang luas. Data di atas dikaitkan dengan konteks sosiokulturan Indonesia yang identik dengan budaya Islam bahwasanya setiap kegiatan harus diawali dengan niat (baik). Pola inferensi inilah yang sesuai dengan proses inferensi data 1.

Data 2: Hewan buas yang mencari ikan salmon di sungai biasanya...

Tersedia 7 kotak huruf, jawaban: BERBURU

Jawaban berburu tidak sesuai dengan prinsip penafsiran lokal. Secara penafsiran lokal stuktur teks memungkinkan jawaban yang berupa jenis ikan atau hewan laut yang biasa memakan ikan salmon di laut, bisa jadi ikan hiu atau ikan yang lainnya. Secara analogi umum pun apa yang tersaji dari struktur teks tersebut tidak memungkinkan jawaban yang berupa kata berburu. Bisa jadi pengecohan struktur teks tersebut digunakan untuk mengecoh penyimak. Analogi-koherensi yang memungkinkan berhubungan dengan kata berburu adalah hewan buas. Dapat disimpulkan jawaban tersebut dapat dicapai melalui analogi lapis kedua melalui koherensi makan hewan buas.

Data 3: Alat musik yang dipukul...

Tersedia 4 kotak huruf, huruf ke-1 D, jawaban: DIAM

Pada data 3 inferensi yang timbul jika menggunakan prinsip analogi maka jawabannya adalah drum. Akan tetapi, jawaban yang muncul mengecoh para pembaca untuk beranalogi demikian. Jawaban diam sama sekali tidak berterima jika proses inferensi menggunakan prinsip analogi dan penafsiran lokal. Analogi yang muncul adalah analogi yang keluar dari batas konvensi umum.

Data 4: Hewan yang dipelihara di akurium...

Tersedia 4 kotak huruf, huruf ke-4 N, jawaban: AMAN

Data 4 memuat teks yang memerlukan inferensi cukup memakan waktu lama karena apabila secara prinsip analogi umum jawaban yang muncul adalah ikan. Ikan adalah bentuk analogi yang paling dekat dan logis karena dinilai koheren dengan kata hewan dan akuarium. Akan tetapi, hal tersebut tidak sesuai dengan koherensi kata dipelihara. Apabila kita mengambil kata kunci dipelihara sebagai alat inferensinya maka jawaban aman menjadi logis.

Data 5: Kampung Rambutan, cililitan, lebak bulus adalah nama...

Tersedia 8 kotak huruf, huruf ke-7 A. jawaban: TERKENAL 
Data lima memiliki konteks situasi tentang Jakarta, karena bintang tamu kuis tersebut adalah Cagub DKI Jakarta. Inferensi secara penafsiran lokal akan muncul jawaban terminal karena ada konteks Jakarta yang melingkupi pertanyaan ini. Kemudian secara linieritas bahasa, antara Kampung Rambutan, Cililitan dan Lebak Bulus adalah tempat terminal. Apabila menggunakan prinsip analogi pun, inferensi yang akan muncul adalah terminal. Jawaban terkenal secara inferensial polanya jauh dari prinsip penafsiran lokal dan analogi umum. Jawaban terkenal masih memiliki koherensi secara analogi, yaitu ada kaitan makna dengan Kampung Rambutan, Cililitan, dan nama Lebak Bulus walau bertentangan dengan sifat pararelisme bahasa yang menyatakan nama-nama tempat tersebut dikenal sebagai nama terminal bukan pada nama terkenalnya.

Data 6: Makanan khas Jakarta yang terbuat dari telor dan laris manis...

Tersedia 10 kotak dengan huruf pertama K dan ketiga R. Jawaban: KERAPHABIS

Jawaban keraphabis merupakan jawaban dengan menggunakan inferensi penafsiran koteks. Hal itu disebabkan karena konteks yang melingkupi yakni, Jakarta dan makan menjadi sesuatu yang dilanggar dalam penyimpulan ini. Hanya melalui ko-teks jawaban itu logis.

Data 7 Si dul adalah anak...

Tersedia 10 kotak huruf pertama B.jawaban : BungsuMaia

Pada data 3 juga memiliki pola inferensi yang melanggar asas konteks kalimat dan koteks wacana. Konteks yang sudah tersedia adala konteks Jakarat sebagai ibu kota Jakarta dan berkembangnya suku betawi. Apabila kita simpulkan secara konteks, inferensi yang akan muncul mengacu kepada tohoh cerita dalam kisah si dul anak Betawi asli. Akan tetapi, dengan munculnya jawaban bungsumaia ini menandakan telah melanggar prinsip penafsiran konteks. Kembali inferensi atau jawaban yang dimunculkan hadir tidak dengan pola inferensi yang wajar. Bungsumaia mengacu kepada anak artis penyanyi terkenal yang memiliki tiga anak dan anak bungsunya sering disapa si dul. Pada dasarnya dalam pertanyaan ini tidak ada perangakat yang memadai untuk membuat simpulan dan jawaban atas pertanyaan ini, karena secara linearitas bahasa pun kurang memadai dan secara analogi lokal pun tidak memadai.

Data 8: Monumen yang ada di Jakarta...

Tersedia 5 kotak huruf, huruf ke-5A. Jawaban KERAS

Data 8 secara penafsiran lokal jawaban yang akan muncul adalah Monas. Hal itu didasari karena secara konteks lokal, yakni mengaitkan kata kunci Jakarta dan Monumen, maka pertanyaan itu mengarah ke jawaban monas. Akan tetapi, ada analogi lain yang tidak umum yang justru muncul sebagai jawaban, yakni keras. Secara analogi memang masih berkaitan antara kata monumen dan keras, yakni sifat monumen yang keras atau tidak berbentuk lembek. Akan tetapi, analogi semacam itu, bertentangan dengan anlogi umum yang lebih dekat dengan konteks pertanyaan tersebut, yakni monumen dan Jakarta. Jawaban keras seakan mencirikan dan menihilkan kata Jakarta sebagai piranti inferensi yang dapat digunakan pembaca. Maka di sini timbul permasalahan analogi. Dapat disimpulkan analogi yang uncul adalah analogi lapis kedua yang melanggar ejaan.

Data 9: Tokoh berkostum kelelawar yg melindungi gotham city...

Tersedia 6 kotak huruf , huruf ke-6 N, jawaban JAGOAN 
Kata jagoan yang muncul sebagai jawaban dari data 9 telah melanggar prinsip penafsiran lokal. Secara konteks lokal tokoh berkostum kelelawar adalah batman. Secara analogi pun antara kata kunci tokoh berkostum kelelawar dan Gotham city pun akan memunculkan jawaban Batman. Jawaban jagoan masih memiliki kaitan makna atau koherensi dengan tokoh berkostum kelelawar, namun analogi itu terlalu jauh bahkan analogi dapat dikatakan itu adalah analogi lapis kedua. Jawaban-jawab yang mengecoh tersebut lebih karena adanya ketidakajegan prinsip analogi dan pelanggran terhadap prinsip penafsiran lokal.

Data 10: Saat memotret model. Kita biasanya pakai...

Tersedia 6 kotak huruf. Huruf akhir A. Jawaban: aba-aba

Data 10 memuat pertanyaan atau teka-teki yang jawabannya keluar dari prinsip penafsiran lokal. Apabila kita buat inferensi secara penafsiran lokal, kata pakai sebagai kata kunci dari teks tersebut biasanya berhubungan denga alat. Alat yang dimaksud adalah alat memotret, yaitu kamera. Jebakan yang dibuat dalam teks tersebut tidak terlepas dari pengecohan prinsip penafsiran lokal. Kata aba-aba tersebut dapat disimpulkan dan ditafsirkan dengan prinsip analogi. Pada data ini jelas jawaba aba-aba adalah jawaban logis berdasarkan prinsip analogi walaupun ada pelanggaran ejaan berkait penulisan aba-aba yang seharusnya memiliki tanda hubung. Data 10 menunjukkan kelogisan yang tidak didapatkan dari data-data sebelumnya.

Data 11: Yang bawa gitar dan mencari nafkah di atas bis. Biasanya ...

Tersedia 8 kotak huruf. Huruf ke 2 E, jawaban: MENYANYI

Sebagaimana pada data 10. Data 11 juga memiliki jawaban yang logis berdasarkan prinsip analogi. Secara analogi kata yang di awal teks menunjukkan orang yang membawa gitar dan mencari nafkah. Berdasarkan pengetahuan umum orang yang membawa gitar dan mencari nafkah disebut pengamen. Akan tetapi, analogi yang muncul adalah analogi lapis kedua yakni bukan pada sebutan profesinya melainkan tindakan dari orang tersebut yang selain bergitar juga biasanya menyanyi. Huruf kedua E merupakan jebakan untuk mengarahkan pembaca pada simpulan pengamen, namun analogi yang muncul adalah menyanyi.

Data 12: Monyet biasanya makan buah...

Tersedia 6 kotak huruf. Huruf ke-5 N. Jawaban: SENANG

Data 12 secara inferensial penafsiran lokan akan memunculkan jawaban pisang. Hal itu dicirikan oleh adanya kata monyet dan pisang apabila kita tafsirkan secara lokal lebih khususnya secara koteks dari kata buah, jawaban pisang adalah yang paling logis. Akan tetapi, jawaban yang dimaksud ternyata keluar dari prinsip penafsiran lokal. Ada analogi yang harus disimpulkan pembaca yang di satu sisi bertentang dengan prinsip penafsiran lokal (konteks buah). Kemunculan jawaban senang secara analogi masih ada kaitan makna namun jauh dari analogi yang terdekat yakni dengan memanfaatkan koherensi kata monyet dan buah. Di sini pun dapat dinyatakan bahwa analogi yang muncul adalah analogi lapis kedua yakni analogi yang jauh dari jangkauan koherensi kata-kata yang ada.

Data 13: Orang menjual sayur dan buah-buahan biasanya di...

Tersedia 5 kotak huruf, huruf ke-5 R, jawaban TAWAR

Jawaban tawar sesuai, jika kita gunakan prinsip penafsiran lokal untuk menyimpulkan pertanyaan teks tersebut. Dalam prinsip penafsiran lokal bentuk di dalam koteks dan konteks di atas menujukkan kata depan atau preposisi. Namun ternyata di tersebut berupa imbuhan yang 
kemudian dilekatkan pada kata tawar. Jawaban tawar (ditawar) menjadi logis apabila kita gunakan prinsip analogi namun analogi yang munculpun menjadi kurang logis jika dikaitkan dengan struktur teks tersebut yang menandakan jawaban yang bersifat tempat. Analogi semacam ini menimbulkan kerancuan dan kegagalan pragmatik karena analogi tersebut seakan loncat dari analogi terdekatnya yakni tempat orang menjual sayur dan buah-buahan. Ada pelanggaran ejaan atau tata tulis karena yang ditebak adalah bukan kata yang lengkap, melainkan kata penggalan atau bagian dari kata, padahal kuis ini sering menanyakan teka tekinya dengan tebak kata.

Sebanyak 11 data yang telah dibahas sebelumnya merupakan hasil inferensi dalam tuturan di acara Waktu Indonesia Bercanda (WIB). Kesebelas data tersebut kemudian direkap dan diberikan keterangan sebagaimana pada Tabel 2.

Tabel 2

Rekapitulasi Hasil Pembahasan

\begin{tabular}{|c|c|c|c|c|}
\hline \multirow[b]{2}{*}{ No } & \multirow[b]{2}{*}{ Data } & \multicolumn{2}{|c|}{ Proses Inferensi } & \multirow[b]{2}{*}{ Keterangan } \\
\hline & & $\begin{array}{c}\text { Penafsiran } \\
\text { Lokal }\end{array}$ & Analogi & \\
\hline 11 & Data 1 & & $\sqrt{ }$ & $\begin{array}{l}\text { Analogi lapis kedua yang mengambil koherensi } \\
\text { dari sebagian kata yang ada dalam teks }\end{array}$ \\
\hline 22 & Data 2 & & $\sqrt{ }$ & Analogi lapis kedua \\
\hline 33 & Data 3 & - & - & $\begin{array}{l}\text { Tidak sesuai prinsip penafsiran lokal dan } \\
\text { analogi }\end{array}$ \\
\hline 44 & Data 4 & - & & Analogi lapis kedua \\
\hline 55 & Data 5 & - & & $\begin{array}{l}\text { Analogi namun melanggar prinsip pararelisme } \\
\text { bahasa }\end{array}$ \\
\hline 66 & Data 6 & - & & Analogi lapis kedua, pelanggaran ejaan \\
\hline 77 & Data 7 & - & & $\begin{array}{l}\text { Pelanggran prinsip penafsiran lokal, analogi } \\
\text { lapis kedua }\end{array}$ \\
\hline 88 & Data 8 & & & Analogi lapis kedua \\
\hline 99 & Data 9 & & & Analogi lapis kedua \\
\hline 110 & Data 10 & & & Analogi pertama \\
\hline 111 & Data 11 & & & Analogi lapis kedua pelanggran struktur \\
\hline 112 & Data 12 & & & Analogi pelanggaran penafsiran lokal \\
\hline 113 & Data 13 & & & Analogi pelanggaran penafsiran lokal \\
\hline
\end{tabular}

Berdasarkan hasil penelitian, banyak ditemukan ketidakajegan pola atau mekanisme inferensi yang ada dalam wacana kuis tebak kata di acara WIB. Ketidakajegan itu ditunjukkan dari inferesnsi data-data yang melanggar aspek penafsiran lokal, dan analogi yang tidak umum. Dalam penelitian ini analogi yang tidak umum tersebut diistilahkan sebagai analogi lapis kedua, yakni analogi yang mengambil sisi koherensi dari sebagian kata yang ada di dalam teks. Jawaban-jawaban dari pertanyaan tersebut menimbulkan kegagaln pragmatik. Selain itu, pelanggaran terhadap kaidah ejaan pun menimbulkan kegagalan pragmatik dalam memahami pertanyaan-pertanyaan dalam kuis tersebut.

Dalam proses inferensi terhadap sebuah teks atau wacana, sebetulnya dapat ditemukan dengan meninjau aspek modalitas yang ada dalam teks. Namun aspek modalitas yang dapat ditelusuri untuk proses inferensi biasanya ada dalam wacana percakapan atau tuturan. Sebagaimana penelitian yang sudah dilakukan terdahulu oleh penulis sendiri terhadap tuturan Gubernur DKI Jakarta pada tahun 2016 yang berkait wacana kalijodo. Akan tetapi, pada wacana tebak kata acara WIB ini tidak ditemukan modalitas yang dapat dijadikan alat analogi untuk 
melakukan inferensi, kecuali pada data 1 ditemukan bentuk modalitas pasti. Namun bentuk pasti dalam data tersebut tidak dapat dijadikan alat untuk mencari inferensinya.

Sementara itu, penelitian Eriyanti (2017) berkait dengan inferensi yang ada dalam pertanyaan guru dalam pembelajaran, terdapat perbedaan antara penelitian ini dengan penelitian yang dilakukan oleh Eriyanti (2017). Penelitian tersebut mengungkapkan bahwa inferensi adalah bagian dari koherensi yang bersifat implisit, sedangkan dalam penelitian ini mekanisme koherensi merupakan bagaian dari prinsip analogi. Sebagaimana yang diungkapkan Mulyana (2005) dan Djadjasudarma (2010) bahwa secara kaidah proses penyimpulan atau penafsiran terhadap suatu teks dilakukan dengan prinsip penafsiran lokal dan analogi.

Prinsip analogi menganjurkan kepada pembaca, pendengar, atau siapa pun yang ingin, mengkaji wacana (baik tulis maupun lisan) agar menyiapkan bekal pengetahuan umum, wawasan yang mendalam, atau pengalaman dunia yang luas (knowledge of world) untuk menganalisis wacana. Sementara itu, penafsiran lokal merupakan prinsip interpretasi lokal dengan cara mencari konteks yang melingkupi wacana. Konteks yang dimaksud dapat berupa latar, tempat berwacana, jenis wacana lisan tulisan, dan waktu kapan wacana dilangsungkan (Mulyana, 2005).

Dalam pandangan lain, Cummings (2007) mengungkapkan bahwa penyimpulan atau inferensi merupakan tindakan membuat informasi yang eksplisit berdasarkan informasi yang implisit dari sebuah wacana/tuturan. Hal itu menandakan bahwa inferensi dapat terjadi melalui proses penafsiran yang kuat terhadap data-data implisit. Di sini ada semacam proses intuitif yang harus dinilai pembaca/penyimak dalam memperoleh jawaban atau simpulan yang tepat sebagaimana yang dimaksud pembuat wacana atau penutur. Dalam wacana tebak kata acara WIB pun kebanyakan dari inferensinya adalah berdasarkan analogi yang hanya mengambil dari sebagian teks. Selebihnya secara intuitif seorang yang menjawab pertanyaan kuis tersebut secara intuitif harus dapat menerka jawaban yang juga disesuikan dengan kotak huruf yang tersedia. Dalam penelitian ini inferensi semcam itu dinamakan analogi lapis kedua.

Berkaitan dengan kotak huruf yang tersedia itu, terkadang proses-proses inferensi menjadi kabur dan penuh dengan jebakan sebagaimana dianalisis dalam bagian temuan hasil, bahwa jumlah huruf yang tersedia dan kata kunci satu huruf yang disediakan sering membentuk inferensi yang bersifat umum. Akan tetapi, pada kenyataannya justru jawabannya jauh dari inferensi yang bersifat umum. Sebagaimana contoh pada data 9. Berdasarkan data tersebut, secara umum orang akan berinferensi batman, namun pada kenyataanya jawaban yang muncul adalah jagoan. Hal inilah yang bersifat pengecohan yang tidak sesuai dengan inferensi umum.

\section{SIMPULAN}

Hasil temuan dan pembahasan menunjukkan bahwa pola-pola inferensi yang muncul dalam wacana tebak kata acara Waktu Indonesia Bercanda (WIB) adalah pola analogi lapis kedua, yakni kegiatan menyimpulkan suatu tuturan secara intutif yang tidak secara langsung beranalogi dengan teks, namun dengan cara menjelajahi berbagai kemungkinan informasi sosiokultural yang luas. Adapun proses penafsiran lokal sebagai prinsip inferensi yang lazim digunakan orang dalam menyimpulkan suatu wacana/tuturan diabaikan bahkan dilanggar.

Selain itu, terdapat pelanggaran terhadap ejaan dan penyimpangan-koherensi koteks, yakni tidak adanya hubungan sintagmatik antara kata terakhir dalam tuturan dengan kata selanjutnya dalam teks, yang dalam hal ini kata tersebut yang menjadi jawaban dari pertanyaan tuturan. Hal ini menunjukkan terdapat pelanggaran-pelanggaran prinsip penafsiran lokal dan prinsip analogi umum (lapis pertama). Hal itu menimbulkan kesalahpahaman bagi para penyimak wacana tersebut. Ketidakajegan pola inferensi dan pelanggaran terhadap prinsip- 
prinsip inferensi inilah yang dimanfaatkan acara Waktu Indonesia Bercanda (WIB) dalam menarik penonton.

\section{DAFTAR PUSTAKA}

Ahmadi, Y. (2016). Analisis Modalitas Tuturan Basuki Cahaya Purnama dalam Wacana Kalijodo. Gramatika: Jurnal Ilmiah Kebahasaan dan Kesastraan, 4(2), 69-77.

Ahmadi, Y., Darmayanti, N., \& Wahya, N. (2017). Analisis Wacana Kritis: Ideologi Hizbut Tahrir Indonesia dalam Wacana Kenaikan Harga BBM 2013 di Buletin Al-Islam yang Berjudul "Menaikkan Harga BBM: Menaikkan Angka Kemiskinan". Metalingua: Jurnal Penelitian Bahasa, 12(2), 253-268.

Ahmadi, Y., \& Mahardika, R. Y. (2016). Analisis Wacana Kohesi dan Koherensi pada Wacana Iklan Politik dalam Wacana Pemilu 2014. P2M STKIP Siliwangi, 3(1), 19-24.

Amin, Z. (2018). Analisis Inferensi Elaboratif Mengandung Pengenalan yang Salah dalam Serial Drama Nihonjin No Shrinai Nihongo Karya Masumoto Takuya Tahun 2011. GoKen, 6(1), 1-10.

Anjani, E. A. (2013). Kohesi dan Koherensi Wacana Stand Up Comedy Prancis dan Indonesia. Jurnal Kawistara, 3(3), 227-334.

Cummings, L. (2007). Pragmatik: Sebuah Perspektif Multidisipliner (E. Setiawati, Trans.). Yogyakarta Pustaka Pelajar.

Djadjasudarma, T. F. (2010). Metode Linguistik: Ancangan Metode Penelitian dan Kajian. Bandung: Refika Aditama.

Djajasudarma, F. (2012). Wacana dan Pragmatik. Bandung: Refika Aditama.

Eriyanti, R. W. (2017). Koherensi Pertanyaan Guru pada Pembelajaran. KEMBARA: Jurnal Keilmuan Bahasa, Sastra, dan Pengajarannya, 2(1), 77-89.

Ghufron, S. (2012). Peranti Kohesi dalam Wacana Tulis Siswa: Perkembangan dan Kesalahannya. Bahasa dan Seni: Jurnal Bahasa, Sastra, Seni, dan Pengajarannya, 40(1), 81-93.

Hanafiah, W. (2015). Analisis Kohesi dan Koherensi pada Wacana Buletin Jumat. Epigram, $11(2), 135-152$.

Lestari, N. P. S., Artika, I. W., \& Indriani, M. S. (2016). Kekohesifan Wacana Opini Majalah Bali Post. Jurnal Pendidikan Bahasa dan Sastra Indonesia Undiksha, 4(2), 1-10.

Marwan, I. (2013). Wujud Kebahasaan dalam Wacana Humor Kajian Semiotika. Jurnal AlTsaqafa, 10(1), 23-34.

Mujianto, G. (2018a). Analisis Wacana Kritis Pemberitaan Tentang Ormas Islam pada Situs Berita Online. KEMBARA: Jurnal Keilmuan Bahasa, Sastra, dan Pengajarannya, 4(2), 155-172.

Mujianto, G. (2018b). Piranti Kohesi dalam Wacana Tulis Guru SMA/SMK Muhammadiyah Kabupaten Malang KEMBARA: Jurnal Keilmuan Bahasa, Sastra, dan Pengajarannya, 3(2), 210-233.

Mulyana, D. (2005). Kajian Wacana: Teori, Metode, dan Aplikasi Prinsip-Prinsip Analisis Wacana. Yogyakarta: Tiara Wacana.

Musaffak, M. (2015). Analisis Wacana Iklan Makanan dan Minuman pada Televisi Berdasarkan Struktur dan Fungsi Bahasa. KEMBARA: Jurnal Keilmuan Bahasa, Sastra, dan Pengajarannya, 1(2), 224-232.

Numertayasa, I. W., \& Sutama, M. (2013). Analisis Wacana Esai Kajian Struktur Supra, Mikro dan Makro pada Esai Hasil Pelatihan Menulis Esai Sekolah Menengah Se-Kecamatan Rendang Tahun 2011. Jurnal Pendidikan dan Pembelajaran Bahasa Indonesia, 2(1), 110. 
Nurshoimah, S., \& Prabowo, A. H. (2016). Inferesi Wacana dalam Karangan Siswa pada Pembelajaran Bahasa Indonesia di SMK Prawira Marta Kartasura Universitas Muhammadiyah Surakarta.

Sidharta, B. A., \& Gunarsa, A. (2016). Pengantar Logika: Sebuah Langkah Pertama Pengenalan Medan Telaah. Bandung Refika Aditama.

Surana, S. (2017). Inferensi dan Problematika Pembelajaran Aanalisis Wacana FKIP $e$ PROCEEDING, 237-244.

Wijoyanto, D. (2018). Hubungan Referensi-Inferensi dalam Wangsalan Sindhenan BASINDO: jurnal kajian bahasa, sastra Indonesia, dan pembelajarannya, 1(2), 40-47.

Wiyanti, E. (2016). Kajian Kohesi Gramatikal Substitusi dan Elipsis dalam Novel "Laskar Pelangi” Karya Andrea Hirata. Jurnal Pendidikan Bahasa dan Sastra UPI, 16(2), 188202. 